Research Article

\title{
Solanum betaceum extract give protective effect on spermatozoa morphology of mice exposed to lead acetate
}

Rima Wirenviona', Reny I’tishom², Siti Khaerunnisa ${ }^{3}$ Anak Agung Istri Dalem Cinthya Riris ${ }^{4}$, Nurul Fatimah Susanti ${ }^{5}$, Nurul Jannatul Wahidah ${ }^{6}$, Abadiyah Zakiyah Kustantina ${ }^{7}$

1,4,5,6,7) Master of Reproductive Health, Faculty of Medicine, Airlangga University, Surabaya.

2) Department of Medical Biology, Faculty of Medicine, Airlangga University, Surabaya.

3) Department of Medical Biochemistry, Faculty of Medicine, Airlangga University, Surabaya.

\section{ART I C LE I N F O}

A R T I C L E I N F O

\begin{tabular}{ll}
\hline Submitted & : April 2020 \\
Accepted & : August 2020 \\
Published & : January 2021 \\
\hline
\end{tabular}

\section{Keywords:}

Solanum betaceum extract, morphology, spermatozoa, lead acetate

\section{*Correspondence:}

ritishom@fk.unair.ac.id

\section{ABSTRACT}

Environmental pollution is one of the factors that contribute to the decline in male fertility. Lead is one of six air pollutants harmful to the reproductive system. One parameter of infertility in men is a decrease in reproductive function observed with increasing abnormalities morphology of spermatozoa. The purpose of this study is to analyze the effect of giving various dosages of Solanum betaceum extract on spermatozoa morphology of mice exposed to lead acetate. This study was true experimental using a randomized post-test only control group design. The total sample was 40 male mice Balb/ $\mathrm{C}$ taken by simple random sampling technique. Treatment and maintenance of experimental animals for 35 days. Statistical tests with one way Anova showed there were significant differences with p-value 0.005 . Solanum betaceum extract can be used as a protective agent to improve the normal morphology spermatozoa of mice that exposed to lead acetate. 


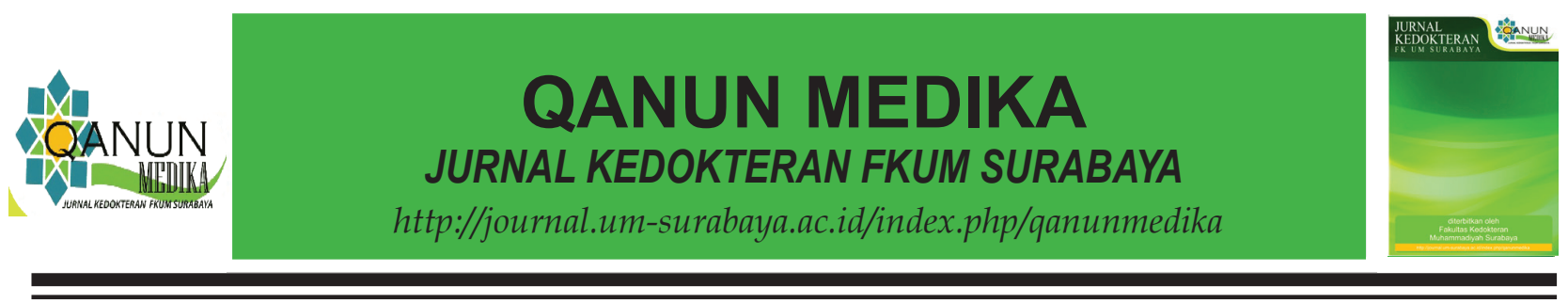

\section{INTRODUCTION}

Environmental pollution is known as one of the factors related to the decline in male fertility (I'tishom, Lubis, Pieters, \& Hamdani, 2011). One parameter of infertility in men is a decrease in reproductive function observed with an increase in abnormalities morphology of spermatozoa (Kumar, 2018). Environmental pollutant material that is often found daily, especially in industrial countries and in developing countries is lead $(\mathrm{Pb})$ (Bierkens, Smolders, Holderbeke, \& Cornelis, 2011). Indonesia ranks fifth after India, China, Vietnam, and the Philippines as lead polluted countries according to the Political and Economic Risk Consultancy (PERC) (Diana, I'tishom, \& Sudjarwo, 2017). Lead acetate given orally in experimental animals can increase levels of Malondialdehyde (MDA) testes and cause changes in the histological features of testicular tissue where interstitial exudation, degeneration, and spermatogenic cell necrosis are seen. This results in impaired spermatozoa quality (Zarghami \& Khosrowbeygi, 2005).

Lead can cause fat oxidation in unsaturated fat chains. Lipids that improve oxidation will be repaired chain reactions to make free radical products. Increasing the number of radicals will spend the amount of decomposition of unsaturated fatty acids into lipids peroxide, which is very unstable. Lipid peroxidation will result in damage to the structure of spermatozoa (Acharya, Acharya, \& Mishra, 2003). The administration of lead nitrate to male mice for 16 days with concentrations of $120 \mathrm{ppm}, 360 \mathrm{ppm}, 600 \mathrm{ppm}$, and 840 ppm, respectively, significantly reduced the process of spermatogenesis in the phases of spermatocytogenesis, meiosis, and spermiogenesis. The toxic effects of lead on the male reproductive system result in testicular atrophy, which affects the morphology of spermatozoa (Suryatini \& Rai, 2018).
Lipid peroxidation reactions can be inhibited by the addition of antioxidants (Chang \& Kim, 2018). One of the natural antioxidants that can be used is Solanum betaceum extract, which is proven to contain relatively high antioxidants such as anthocyanin, flavonoids, carotenoids, tannins, and saponins (Khaerunnisa, Kusumastuti, Mustika, Aminah, \& Suhartati, 2019; Rosadi, Warditiani, \& Larasanty, 2018). High antioxidants can reduce lead-induced oxidative stress in experimental animals (Diana et al., 2017). Antioxidant performance by inhibiting the formation of Reactive Oxygen Species (ROS), preventing redox reactions that produce new oxidants, protecting lipophilic antioxidants to strengthen endogenous antioxidants (Hardiningtyas, Purwaningsih, \& Handharyani, 2014), and working with testosterone for spermatozoa maturation (Türk et al., 2008). Based on the explanation, Solanum betaceum extract is expected to act as an antioxidant by preventing damage to biological membranes due to free radicals and potentially as a spermatozoa protective agent from the influence of lead acetate.

\section{METHODS}

This research was conducted after obtaining permission from the committee of Ethics of Medical Faculty, Airlangga University, with letter number 30/EC/KEPK//FKUA/2020. This research is true experimental research using a randomized post-test only control group design to determine the effect of Solanum betaceum extract on the spermatozoa morphology of male mice exposed to lead acetate. This research has been conducted in January-February 2020 by involving 40 mice $\mathrm{Balb} / \mathrm{C}$.

The research sample was selected by a simple random sampling technique and divided into five groups, namely $\mathrm{K} 0, \mathrm{~K} 1, \mathrm{P} 1, \mathrm{P} 2$, and P3. $\mathrm{K} 0$ received distilled water only. K1 received a lead acetate dose $75 \mathrm{mg} / \mathrm{kg}$ BW. P1, P2, and P3 received ethanol extract of Solanum 
betaceum with three different doses, namely $100 \mathrm{mg} / \mathrm{kg} \mathrm{BW}, 200 \mathrm{mg} / \mathrm{kg} \mathrm{BW}$, and $400 \mathrm{mg} /$ $\mathrm{kg} \mathrm{BW}$, respectively. The inclusion criteria of this research were male mice Balb/C, age \pm 12 weeks, and initial body weight of 25-30 grams. Research exclusion of experimental animals was sick and died.

After 35 days of treatment, the spermatozoa will be examined to determine its morphology. Spermatozoa suspension was taken using a dissecting kit to remove the epididymis organs. The epididymal fluid was released and suspended with $\mathrm{NaCl} 0.9 \%$ in a microtube. Spermatozoa suspension from cauda epididymis was used for observation. Observation of spermatozoa morphology is done by spermatozoa suspension results dripped on the glass object. Preparations are dried in the air before fixation. The preparation was fixed with methanol for
5 minutes and dried again. Furthermore, the preparation was stained with safranin for 5 minutes and rinsed with phosphate buffer solution, and then stained with violet crystals for 5 minutes. The practices are washed with clean water and dried. The observation is to see the spermatozoa deformity and its percentage, using a 1000x magnification microscope.

The normality and homogeneity of the data are tested first. Data was said to be normal and homogeneous if the p-value $>0.05$. The normality test used Shapiro-Wilk because of the data $<50$. After the data is declared normal and homogeneous, it is continued with Anova test. P-value $<0.05$ is the significance value of the variables analyzed with one way Anova. After an Anova test shows the significant result, then continue with the Post hoc test to know which group is different from the others.

\section{RESULTS}

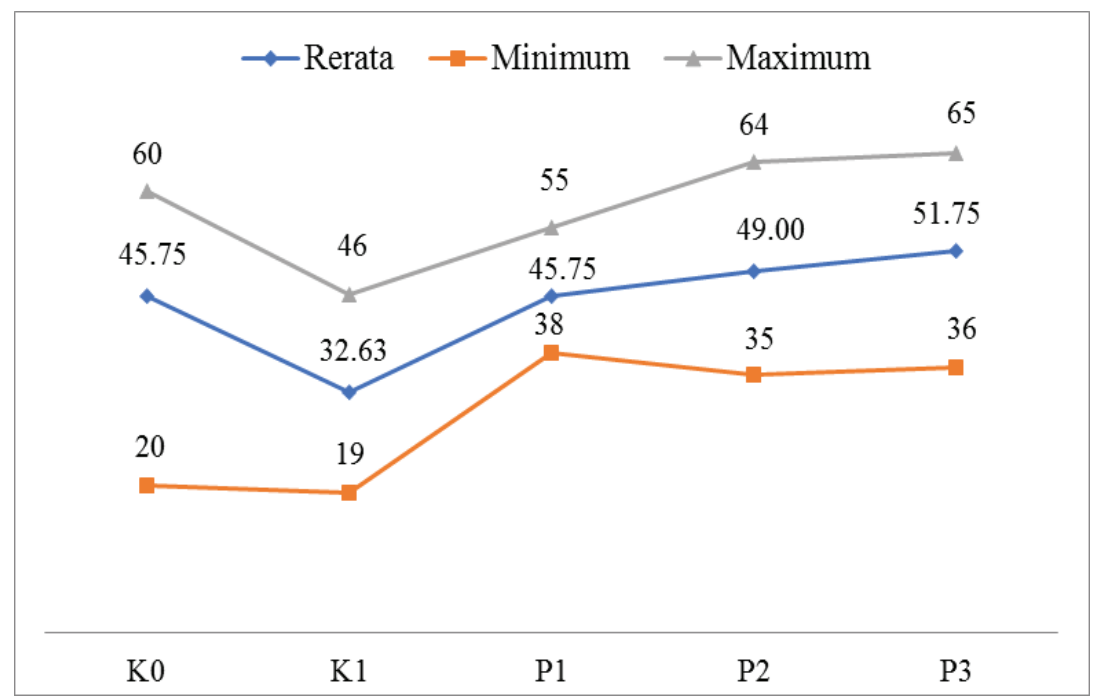

Figure 1. Average, minimum, and maximum on the normal morphology of spermatozoa

Table 1. Statistical test results on the normal morphology of spermatozoa

\begin{tabular}{|c|c|c|c|c|c|c|}
\hline Group & Sample & Mean & $\begin{array}{l}\text { Standard } \\
\text { Deviation }\end{array}$ & $\begin{array}{c}\text { Normality } \\
\text { test }\end{array}$ & $\begin{array}{c}\text { Homogeneity } \\
\text { test }\end{array}$ & $\begin{array}{c}\text { Anova } \\
\text { test }\end{array}$ \\
\hline $\mathrm{K}_{0}$ & 8 & 45.75 & 12.464 & 0.371 & \multirow{5}{*}{0.397} & \multirow{5}{*}{0.005} \\
\hline $\mathrm{K}_{1}$ & 8 & 32.63 & 9.501 & 0.618 & & \\
\hline$P_{1}$ & 8 & 45.75 & 5.922 & 0.887 & & \\
\hline $\mathrm{P}_{2}$ & 8 & 49.00 & 9.274 & 0.990 & & \\
\hline $\mathrm{P}_{3}$ & 8 & 51.75 & 11.081 & 0.279 & & \\
\hline
\end{tabular}




\section{QANUN MEDIKA Vol 5 No 1 JANUARY 2021}

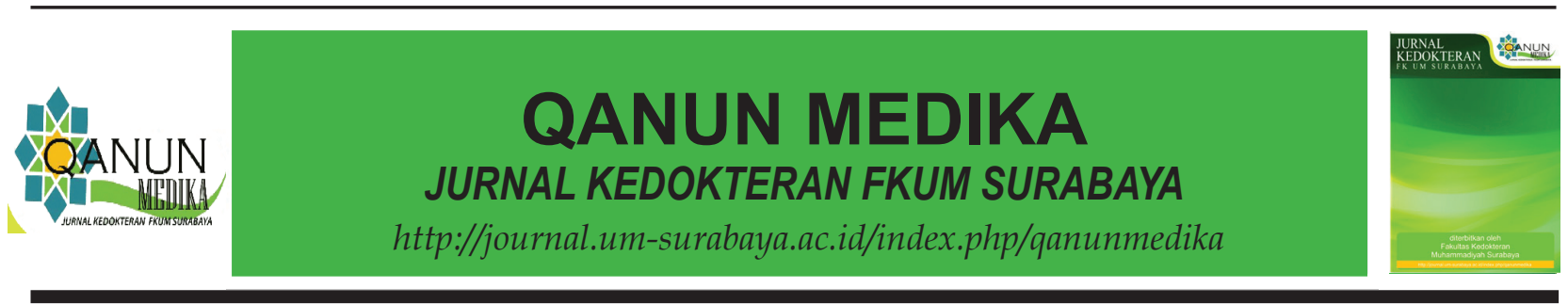

Table 2. Post hoc LSD test on the normal morphology of spermatozoa

\begin{tabular}{ccccc}
\hline Group & $\mathbf{K}_{\mathbf{0}}$ & $\mathbf{K}_{\mathbf{1}}$ & $\mathbf{P}_{\mathbf{1}}$ & $\mathbf{P}_{\mathbf{2}}$ \\
\hline $\mathrm{K}_{1}$ & $0.012^{\mathrm{a}}$ & - & - & - \\
$\mathrm{P}_{1}$ & 1.000 & $0.012^{\mathrm{b}}$ & - & - \\
$\mathrm{P}_{2}$ & 0.516 & $0.002^{\mathrm{c}}$ & 0.516 & - \\
$\mathrm{P}_{3}$ & 0.233 & $0.000^{\mathrm{d}}$ & 0.233 & 0.582 \\
\hline
\end{tabular}

Information: Superscript letters show significant differences $(\mathrm{p}<0.05)$

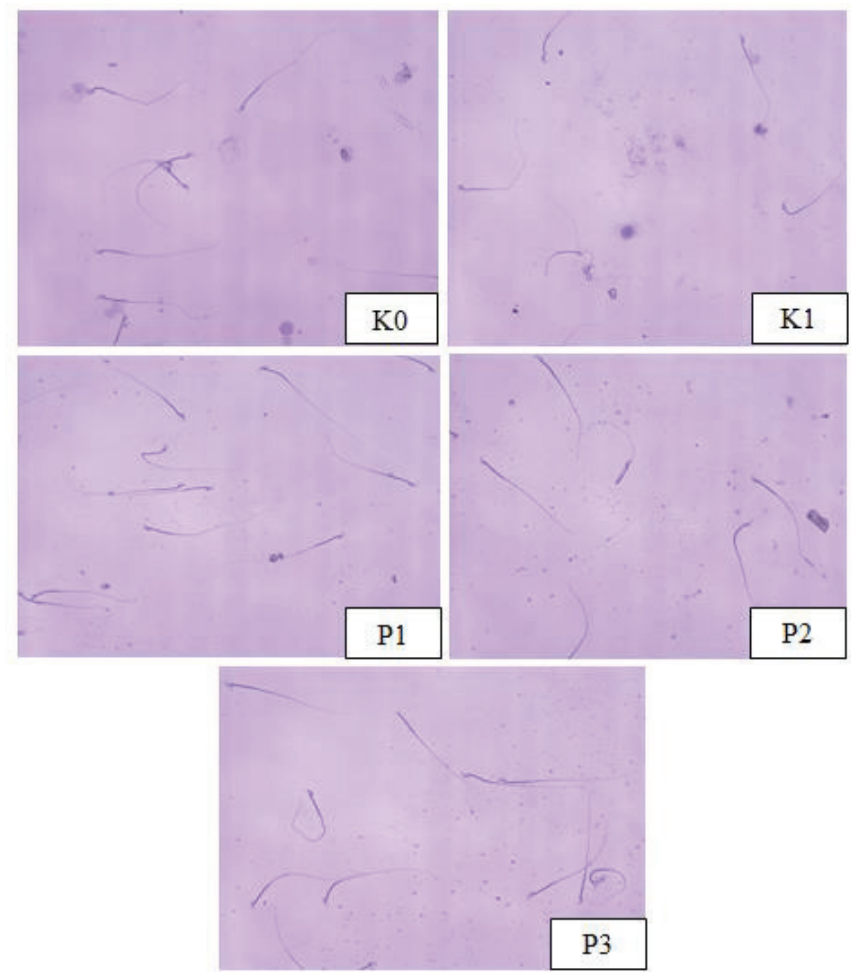

Figure 2. The effect of treatment on the spermatozoa morphology. K0 received distilled water; K1 received lead acetate $75 \mathrm{mg} / \mathrm{kg}$ BW; P1 received Solanum betaceum $100 \mathrm{mg} / \mathrm{kg} \mathrm{BW;} \mathrm{P2}$ received Solanum betaceum 200 mg/kg BW; P3 received Solanum betaceum 400 mg/kg BW.

\section{DISCUSSION}

Based on picture 1, the mean of normal morphology spermatozoa in each group has a difference. The highest mean was $51.75 \%$ in $\mathrm{P} 3$, and the lowest mean was $32.63 \%$ in $\mathrm{K} 1$. The mean and maximum values of normal morphology spermatozoa in groups P1, P2, and P3 increased with increasing doses. Table 1 showed the statistical test of normal morphology spermatozoa. Shapiro-Wilk test showed that all data distribution was normal with $p$-value $>0.05$. Data was homogenous with $\mathrm{p}$-value $=0.397$. Anova test showed that there were significant differences in spermatozoa morphology with a p-value $=0.005$. The test was continued with Post hoc LSD to determine differences in normal morphology of spermatozoa between groups. Based on table 2, the Post hoc LSD results showed that there were significant differences in the normal morphology of spermatozoa with a p-value $<0.05$ in other words, between $\mathrm{K} 0$ with $\mathrm{K} 1$ of $0.012, \mathrm{~K} 1$ with $\mathrm{P} 1$ of $0.012, \mathrm{~K} 1$ with $\mathrm{P} 2$ of 0.002 , and K1 with P3 of 0.000 . 
Spermatozoa morphology can be influenced by the toxic effects of lead, which disrupts the process of spermatogenesis by impairing hormone synthesis and regulation (Kumar, 2018). It is evident that most of the disruptors of sperm function, be it endogenous, environmental, of lifestyle mediated, may operate via unregulated ROS. This leads to a condition of oxidative stress with the generation of reactive species (oxidants) superseding total antioxidant capacity (reductants) in the seminal plasma (Parekattil, Esteves, \& Agarwal, 2020). The targets of ROS are lipids, proteins, and DNA (Sudjarwo, 2004). Spermatozoa contain large quantities of polyunsaturated fatty acids (PUFA), and therefore they are susceptible to ROS-induced damage. It has been suggested that ROS induce membrane lipid peroxidation in spermatozoa and that the toxicity of generated fatty acid peroxides is an important cause of spermatozoa malfunction (Zarghami \& Khosrowbeygi, 2005).

ROS is vital to fight foreign pathogens in normal amounts, whereas excessive amounts of ROS oxidize it (Ardiaria, 2019). K1 shows that the excessive production of ROS can inflict severe damage to spermatozoa. This study showed the group had the lowest normal morphology of spermatozoa with a mean of $32.63 \%$. Based on picture 2 , high head, neck, and tail defect rates occurred in the K1 group given lead acetate. The administration of lead stimulates a constant increase in abnormal spermatozoa or teratozoospermia (Acharya, Acharya, and Mishra, 2003). It has been demonstrated that the morphologically abnormal spermatozoa are very active in ROS productions (Sabeti, Pourmasumi, Rahiminia, Akyash, \& Talebi, 2016). Normal physiological events in sperm maturation include extrusion of excess cytoplasm. However, when spermiogenesis is disrupted, spermatozoa retain excess cytoplasm around the midpiece, thus impeding its function (excess residual cytoplasm, ERC). Immature spermatozoa with distorted head morphology and cytoplasmic retention are, therefore, a major source of seminal ROS (Parekattil et al., 2020).

The present study was designed to evaluate the protective effects of exogenous antioxidants on testis tissue and assess the improvement of normal morphology spermatozoa in experimental animals. Normal cell function is related to the continuous removal of excess ROS with seminal plasma antioxidants. Antioxidants suppress the formation of new ROS or act as scavengers and remove ROS already generated (Mortazavi, Salehi, Alizadeh, Mehrangiz, \& Roushandeh, 2014). Solanum betaceum is a fruit that contains high antioxidants. Based on the phytochemical screening test, Solanum betaceum extract is known to positively have phenol, flavonoid, tannin, anthocyanin, and saponin compounds (Khaerunnisa et al., 2019; Rosadi et al., 2018).

Flavonoid compound is a secondary metabolite compound that acts as an antioxidant because it is beneficial in preventing cell damage due to oxidative stress (Widayanti, Puspawati, Suarsana, Asih, \& Rita, 2016). Flavonoids that function as antioxidants are flavonoids that have hydroxyl groups $(-\mathrm{OH})$ because they can donate protons ( $\mathrm{H}$ atoms) to free radicals so that free radicals become stable (Kaur \& Mondal, 2014). Ellagic acid in tannins reacts with free radicals because of its ability to bind metal ions, which are potent antioxidants against lipid peroxide (Tukiran, Wardana, Hidayati, \& Shimizu, 2018). Anthocyanin in Solanum betaceum is a natural source of antioxidants that can be used to minimize oxidation reactions and ward off free radicals (Devi, Wipradnyadewi, \& Yusa, 2018). So, high antioxidants can reduce leadinduced oxidative stress (Diana et al., 2017).

The administration of antioxidants in the form of Solanum betaceum extract has been shown to reduce abnormal spermatozoa with the 
mean normal morphology of spermatozoa, which have increased respectively in P1, P2, and P3 to $45.75 \%, 49.00 \%$, and $51.75 \%$ (table 1). The normal morphology percentage of spermatozoa was higher in group P3 than in group $\mathrm{K} 0$ given distilled water only. This situation because the ROS levels can be tolerated by the antioxidant content of Solanum betaceum extract, especially given at a dose of $400 \mathrm{mg} / \mathrm{kg} \mathrm{BW}$. An increase in the mean of normal morphology spermatozoa in the treatment group during 35 days showed the effectiveness of the antioxidant action contained in the extract of Solanum betaceum. Antioxidant performance is thought to play an important role during the process of spermatogenesis, especially in the process of spermiogenesis and maturation of spermatozoa.

The performance of flavonoids in the body can bind to alpha estrogen receptors (RE $\alpha)$ in the testes and epididymis, which can replace estrogenic function and work together with testosterone for spermatozoa maturation (Setyawan et al., 2017). The perfect form of spermatozoa is an elongated cell consisting of a blunt head in which there are a nucleus and a tail containing apparatus for cell movement. There is an acrosome on the head that has a dual-wall structure that is located between the plasma membrane of the anterior nucleus. The neck part will connect the head and tail (flagella), which are divided again into the middle, main, and end parts which have different structures (Panggabean, Soeng, \& Ivone, 2008). Antioxidants are given in treatment groups able to delay, prevent, or eliminate oxidative damage from a highly reactive target molecule such as free radicals. High antioxidants can reduce lead-induced oxidative stress in animal experiments. Solanum betaceum is an exogenous antioxidant that provides protective benefits for the morphology of spermatozoa. The limitations of this study were that it only assessed 3 different dose variations of the Solanum betaceum extract.

\section{CONCLUSION}

The administration of Solanum betaceum extracts significantly affected the morphology of spermatozoa. The highest increase in the mean of normal morphology spermatozoa is shown by administering a dose of $400 \mathrm{mg} / \mathrm{kg} \mathrm{BW}$. The mean of normal morphology spermatozoa was higher in the P3 group that received $400 \mathrm{mg} /$ $\mathrm{kg} \mathrm{BW}$ compare to the $\mathrm{K} 0$ group that did not get the extract. Solanum betaceum has potential as a candidate for fertility compounds in the development of preventive exposure to toxic materials.

\section{REFERENCES}

Acharya, U. R., Acharya, S., \& Mishra, M. (2003). Lead Acetate Induced Cytotoxicity in Male Germinal Cells of Swiss Mice. Industrial Health, 41(3), 291-294. https:// doi.org/10.2486/indhealth.41.291

Ardiaria, M. (2019). Disfungsi Mitokondria Dan Stress Oksidatif. Journal of Nutrition and Health, 7(3), 50-55. https://doi. org/10.14710/jnh.7.3.2019.50-55

Bierkens, J., Smolders, R., Holderbeke, M. Van, \& Cornelis, C. (2011). Predicting Blood Lead Levels from Current and Past Environmental Data in Europe. Science of the Total Environment, 409(23), 5101-5110. https://doi.org/10.1016/j. scitotenv.2011.08.034

Chang, E., \& Kim, C. Y. (2018). Lipid Peroxidation and Antioxidant Activities of the Aqueous Rhizome Extract of Rheum officinale Baillon. Journal of Food Quality, 2018, 1-7. https://doi. org/10.1155/2018/5258276 
Devi, N. P. A., Wipradnyadewi, P. A. S., \& Yusa, N. M. (2018). Pengaruh Penambahan Terung Belanda (Solanum betaceum Cav.) Terhadap Karakteristik Marshmallow. ITEPA, 7(1), 23-32.

Diana, A. N., I'tishom, R., \& Sudjarwo, S. A. (2017). Nigella sativa Extract Improves Seminiferous Tubule Epithelial Thickness in Lead Acetate-Exposed Balb/C Mice. Folia Medica Indonesiana, 53(3), 180 184.

Hardiningtyas, S. D., Purwaningsih, S., \& Handharyani, E. (2014). Antioxidant Activity and Hepatoprotective Effect of Green Mangrove Leaves. JPHPI, 17(1), 80-91.

I'tishom, R., Lubis, K. S., Pieters, O., \& Hamdani, S. (2011). The Changes of The Spermatozoa Concentration In Men Exposed To Vehicle Exhaust Emissions In Surabaya In 2007. Jurnal Kesehatan Reproduksi, 1(2), 67-72.

Kaur, S., \& Mondal, P. (2014). Study of Total Phenolic and Flavonoid Content, Antioxidant Activity, and Antimicrobial Properties of Medicinal Plants. Journal of Microbiology \& Experimentation, 1(1), 23-28. https://doi.org/10.15406/ jmen.2014.01.00005

Khaerunnisa, S., Kusumastuti, K., Mustika, A., Aminah, N. S., \& Suhartati, S. (2019). Mechanism of Solanum betaceum to Prevent Memory Impairment in Cigarette Smoke-Exposed Rat. International Journal of Applied Pharmaceutics, 11(3), 25-29.

Kumar, S. (2018). Occupational and Environmental Exposure to Lead and Reproductive Health Impairment: An Overview. Indian J Occup Environ Med, 22(3), 128-137. https://doi.org/10.4103/ ijoem.IJOEM_126_18
Mortazavi, M., Salehi, I., Alizadeh, Z., Mehrangiz, V., \& Roushandeh, A. M. (2014). Protective Effects of Antioxidants on Sperm Parameters and Seminiferous Tubules Epithelium in High Fat-fed Rats. Journal of Reproductive \& Infertility, 15(1), 22-28.

Panggabean, P. C. ., Soeng, S., \& Ivone, J. (2008). Efek Pajanan Timbal terhadap Infertilitas Pria. Jkm, 8(1), 87-93.

Parekattil, S. J., Esteves, S. C., \& Agarwal, A. (Eds.). (2020). Male Infertility, Contemporary Clinical Approaches, Andrology, ART, and Antioxidants (2nd ed.). Switzerland: Spinger.

Rosadi, A., Warditiani, N., \& Larasanty, L. (2018). Efek Hipoglikemia Ekstrak Buah Terung Belanda ( Solanum betaceum Cav .) pada Mencit Jantan Galur Balb / C. Jurnal Farmasi Udayana, 7(2), 63-67.

Sabeti, P., Pourmasumi, S., Rahiminia, T., Akyash, F., \& Talebi, A. R. (2016). Etiologies of Sperm Oxidative Stress. International Journal of Reproductive BioMedicine, 14(4), 231-240. https://doi. org/10.29252/ijrm.14.4.231

Setyawan, M. E. A., Romadhon, Y. A., Sintowati, R., Sutrisna, E., Nugraha, O. Y., \& Afwan, F. 'Mushalim. (2017). The Effect of Kalimantan's Honey Propolis Toward the Quality of Mice's (Mus musculus 1.) Spermatozoa That Exposed by Cigarette Some. Asian Journal of Biochemical and Pharmaceutical Research, 7(2), 70-75.

Sudjarwo. (2004). 8-Hidroksi-Deoksiguanosin sebagai Salah Satu Indikator Infertilitas Pria. Berk. Penel. Hayati, 10, 43-47.

Suryatini, K. Y., \& Rai, I. G. A. (2018). Logam Berat Timbal $(\mathrm{Pb})$ dan Efeknya pada Sistem Reproduksi. Emasains, 7(1), 1-6. 
Tukiran, Wardana, A. P., Hidayati, N., \& Shimizu, K. (2018). An ellagic Acid Derivative and Its Antioxidant Activity of Chloroform Extract of Stem Bark of Syzygium polycephalum Miq. (Myrtaceae). Indonesian Journal of Chemistry, 18(1), 26-34. https://doi. org/10.22146/ijc. 25467

Türk, G., Sönmez, M., Aydin, M., Yüce, A., Gür, S., Yüksel, M., ... Aksoy, H. (2008). Effects of Pomegranate Juice Consumption on Sperm Quality, Spermatogenic Cell Density, Antioxidant Activity, and Testosterone Level in Male Rats. Clinical Nutrition, 27(2), 289-296. https://doi.org/10.1016/j. clnu.2007.12.006
Widayanti, N. P., Puspawati, N. M., Suarsana, I. N., Asih, I. A. . A., \& Rita, W. S. (2016). Aktivitas Antioksidan Fraksi N-Butanol Ekstrak Kulit Terong Belanda (Solanum Betaceum Cav.) Secara in Vitro Dan Identifikasi Senyawa Golongan Flavonoidnya. CAKRA KIMIA(Indonesian E-Journal of Applied Chemistry), 4(1), 30-37.

Zarghami, N., \& Khosrowbeygi, A. (2005). Seminal Plasma Levels of 15-F2 $\alpha$-Isoprostane, Malondialdehyde, and Total Homocysteine in Normozoospermic and Asthenozoospermic Males. Indian Journal of Clinical Biochemistry, 20(2), 86-91. 